\title{
Reversible Decomposition of Secondary Phases in BaO Infiltrated LSM Electrodes- Polarization Effects
}

Traulsen, Marie Lund; McIntyre, Melissa D.; Norrman, Kion; Sanna, Simone; Mogensen, Mogens Bjerg; Walker, Robert A.

Published in:

Advanced Materials Interfaces

Link to article, DOI:

10.1002/admi.201600750

Publication date:

2016

Document Version

Peer reviewed version

Link back to DTU Orbit

Citation (APA):

Traulsen, M. L., McIntyre, M. D., Norrman, K., Sanna, S., Mogensen, M. B., \& Walker, R. A. (2016). Reversible Decomposition of Secondary Phases in BaO Infiltrated LSM Electrodes-Polarization Effects. Advanced Materials Interfaces, [1600750]. https://doi.org/10.1002/admi.201600750

\section{General rights}

Copyright and moral rights for the publications made accessible in the public portal are retained by the authors and/or other copyright owners and it is a condition of accessing publications that users recognise and abide by the legal requirements associated with these rights.

- Users may download and print one copy of any publication from the public portal for the purpose of private study or research.

- You may not further distribute the material or use it for any profit-making activity or commercial gain

- You may freely distribute the URL identifying the publication in the public portal 
DOI: 10.1002/ ((please add manuscript number))

\section{Full Paper}

\section{Reversible Decomposition of Secondary Phases in BaO Infiltrated LSM Electrodes - Polarization Effects}

Marie L. Traulsen*, Melissa D. McIntyre, Kion Norrman, Simone Sanna, Mogens B. Mogensen and Robert A. Walker

Dr. M. L. Traulsen, Dr. K. Norrman, Dr. S. Sanna, Prof. M. B. Mogensen

Department of Energy Conversion and Storage, Technical University of Denmark Frederiksborgvej 399, 4000 Roskilde, Denmark

E-mail: matr@dtu.dk

M. D. McIntyre, Prof. R. A. Walker

Department of Chemistry and Biochemistry, Montana State University

Bozeman, MT 59717-1734, Montana, USA

Keywords: fuel cells, in operando, LSM, Raman spectroscopy, infiltration

In operando Raman spectroscopy is used to study ceramic $\mathrm{La}_{0.85} \mathrm{Sr}_{0.15} \mathrm{MnO}_{3 \pm \delta}$ (LSM)

electrodes infiltrated with $\mathrm{BaO}$. The aim of this work is to clarify why $\mathrm{BaO}$ infiltration reduces the polarization resistance in oxygen containing atmospheres. Prior to the in operando experiments, ex situ XRD and Raman spectroscopy reveals the formation of a secondary phase, $\mathrm{Ba}_{3} \mathrm{Mn}_{2} \mathrm{O}_{8}$, on the electrode. During the in operando Raman investigation of the $\mathrm{BaO}$ infiltrated $\mathrm{La}_{0.85} \mathrm{Sr}_{0.15} \mathrm{MnO}_{3 \pm \delta}$ electrodes, experiments are performed at $300{ }^{\circ} \mathrm{C}$ and $500{ }^{\circ} \mathrm{C}$ with oxygen partial pressure $0.1 \mathrm{~atm}$ and with $-1 \mathrm{~V}$ or $+1 \mathrm{~V}$ applied potential. A changing electrode surface is observed during operation as the $\mathrm{Ba}_{3} \mathrm{Mn}_{2} \mathrm{O}_{8}$ secondary phase decomposes and manganese oxide accumulates on the electrode surface during cathodic polarization. The observed changes are reversible. These results suggest that the formation of $\mathrm{Ba}_{3} \mathrm{Mn}_{2} \mathrm{O}_{8}$ is responsible for the reduced polarization resistance observed at OCV in an oxygen containing atmosphere. Furthermore, the results illustrate the dramatic differences between the electrode 


\section{WILEY-VCH}

surface composition at OCV and during cathodic polarization. Overall, the results highlight the dynamic interactions between minor secondary phases and applied potential, a general effect that may be important for the high performance frequently observed with ceramic electrodes prepared by infiltration.

\section{Introduction}

Understanding the surface chemistry of ceramic electrodes is important for a diverse range of electrocatalytic technologies including fuel cells ${ }^{[1]}$, electrolysis cells ${ }^{[2]}$ and electrochemical gas purification systems. ${ }^{[3]}$ A popular approach for improving the electrocatalytic properties of ceramic electrodes employs infiltration during electrode manufacturing. ${ }^{[4,5]}$ During the infiltration step, a material is added in the form of an aqueous precursor solution to an existing scaffold, where the desired material forms during subsequent conditioning of the electrode. ${ }^{[5]}$ An unintended consequence of this approach can be the formation of minor secondary phases, either from the infiltrate itself ${ }^{[6]}$, or from reactions between the infiltrate and the scaffold. ${ }^{[7]}$ Recent investigations on $\mathrm{La}_{1-x} \mathrm{Sr}_{x} \mathrm{CoO}_{3-\delta}$ (LSC) based electrodes have indicated that the presence of minor secondary phases may even improve electrode performance ${ }^{[6,8-10]}$ due to the formation of hetero-interfaces. ${ }^{[8-10]}$ These and other studies of secondary phases often draw conclusions correlating electrode composition with performance based on ex situ studies and in operando electrochemical characterization. The ex situ analyses performed before and after usage provide valuable insight into irreversible changes that occur in electrode composition and structure while in operando electrochemical measurements report on how performance changes with different operating conditions. Both approaches - ex situ studies and in operando electrochemical characterization - fail to produce direct molecular and materials specific information about the chemical condition of the electrode in operando. Electrochemical characterization and materials specific data acquired in operando are 


\section{WILEY-VCH}

necessary to understand and improve electrocatalytic properties such as activity, selectivity and durability. Here we define in situ studies as studies in which one or two parameters such as temperature, electrical polarization, or atmosphere reflect operating conditions while in in operando studies all three parameters correspond to realistic values during operation of ceramic electrodes. The importance of such measurements was demonstrated recently by Backhaus-Ricoult et al. ${ }^{[11]}$ and Siebert et al. ${ }^{[12]}$ who employed in situ XPS and in operando Raman spectroscopy, respectively, in studies of perovskite based electrodes and their electrocatalytic properties. Data showed reversible changes in composition ${ }^{[11]}$ and structure ${ }^{[12]}$ of perovskite oxide electrodes during electrical polarization that could only be observed with in operando spectroscopic measurements. When the electrode returned to open circuit voltage (OCV), the electrode composition resumed its pre-operational state.

One of the most thoroughly investigated perovskites used for ceramic electrodes has been strontium doped lanthanum manganite (LSM), primarily due to the material's high electronic conductivity at high temperatures and the good compatibility with the commonly used yttria stabilized zirconia (YSZ) electrolyte. ${ }^{[13]}$ In order to improve the performance of LSM based electrodes for SOFC applications, especially at lower temperatures, experiments with infiltrated LSM electrodes have been conducted including infiltration of the entire LSM phase ${ }^{[14-16]}$, infiltration with noble metals or single oxides as “dopants” ${ }^{[17-19]}$ and infiltration with high performance oxygen ion conductors. ${ }^{[5]}$ Similarly, LSM based electrodes for electrochemical gas purification have been infiltrated to improve their electrocatalytic properties towards conversion of gaseous pollutants. ${ }^{[20-23]}$ Infiltration with $\mathrm{BaO}$, possibly with $\mathrm{BaCO}_{3}$ as the final product has been observed to cause a significant reduction in the polarization resistance on LSM-based electrodes. ${ }^{[21,24,25]}$ The effect of the $\mathrm{BaO}$ infiltration has been attributed to changes in processes related to adsorption, dissociation and charge transfer for the gaseous reactant; however, exactly how $\mathrm{BaO}$ infiltration affects these 


\section{WILEY-VCH}

processes has not yet been clarified ${ }^{[21,24,25]}$, and as pointed out by Hong et al. ${ }^{[24]}$ attention should be paid to the chemical bonding state of the Ba atom in the surface of the electrodes. In order to identify the reason(s) for improved performance observed with $\mathrm{BaO}$ modified LSM electrodes in an oxygen atmosphere ${ }^{[21,24,25]}$ and to identify the behavior of secondary phases under operating conditions, the studies described in this work employed in operando Raman spectroscopy coupled with electrochemical measurements. Thin film LSM model electrodes with and without $\mathrm{BaO}$ modification were employed, and the studies were conducted under realistic operating conditions for intermediate temperature SOFCs and electrochemical gas conversion cells. Changes in electrode composition were examined as a function of temperature and electrical polarization. The data suggest that at OCV conditions $\mathrm{Ba}_{3} \mathrm{Mn}_{2} \mathrm{O}_{8}$, a secondary phase formed during the infiltration step, is responsible for the reduced polarization resistance. Furthermore the data showed significant, reversible changes in the electrode surface composition with an applied electrical polarization on the electrodes, resulting in a change in the $\mathrm{MnO}_{\mathrm{x}}$ species at the electrode surface and reversible decomposition of a secondary phase, $\mathrm{Ba}_{3} \mathrm{Mn}_{2} \mathrm{O}_{8}$, with cathodic polarization.

\section{Results}

LSM thin film electrodes were characterized by TOF-SIMS and XPS before and after the in operando Raman spectroscopy. Results from the pre- and post-characterization are described below together with the in operando Raman spectroscopy results. Furthermore, evidence of the secondary $\mathrm{Ba}_{3} \mathrm{Mn}_{2} \mathrm{O}_{8}$ phase in a conventional, porous LSM-CGO electrode is reported.

\subsection{Pre-characterization of LSM thin films}

The LSM electrodes used in these studies had the nominal composition $\left(\mathrm{La}_{0.85} \mathrm{Sr}_{0.15}\right)_{0.9} \mathrm{MnO}_{3 \pm \delta}$, where the LSM perovskite structure had a slight deficiency on the A-site. Four of these LSM thin films without $\mathrm{BaO}$ were characterized by means of TOF-SIMS and XPS. A 


\section{WILEY-VCH}

representative TOF-SIMS depth profile for one of the thin films is shown in Figure 1, after the signal intensity for the individual elements has been corrected for the total signal intensity to minimize instrumental effects. The TOF-SIMS profile (Figure 1) shows an approximately 25 nm thick surface layer of the LSM with a composition deviating from the bulk LSM composition (TOF-SIMS measurements have a depth resolution of $\approx 2 \mathrm{~nm}$ for these materials). Within this surface layer, Mn appears to be depleted and La enriched compared to the bulk values for LSM. Variation in the concentration profiles of individual elements is also observed throughout the layer (Figure 1b). Compared to bulk LSM, Sr appears to be enriched within the $5 \mathrm{~nm}$ layer next to the gas-solid interface and depleted at depths from $5 \mathrm{~nm}$ to 25 $\mathrm{nm}$. The Mn concentration within the first $5 \mathrm{~nm}$ next to the gas-solid interface shows a slight increase towards the interface but never exceeds the bulk value. Furthermore, the $\mathrm{LaO}$ concentration profile reaches a maximum at $7 \mathrm{~nm}$ 's depth. Overall these distributions indicate the existence of two surface layers: a top layer dominated by Sr and Mn and an inner layer enriched in La. These findings agree with reports from similarly prepared electrodes. ${ }^{[26]}$ We note that care must be taken when interpreting TOF-SIMS profiles on LSM electrodes, as matrix-effect may cause artifacts to appear in the concentration profile. ${ }^{[26]}$ For this reason the four LSM electrodes were analyzed by XPS to yield quantitative information on the electrode composition within a probe depth of 5-10 nm. The results from the XPS analysis of four LSM films are reported in Table 1, where the measured ratios between the elements are compared to the theoretical ratios. The XPS results are in agreement with the results from the TOFSIMS depth profile and show enrichment in A-site cations (La, Sr) relative to the B-site cation (Mn), with the Sr enrichment being more pronounced than the La enrichment. Sr segregation on the surface of perovskites has been observed previously and is believed to influence the electrode performance, but the specific influence of Sr's enrichment at the electrode surface is still debated. ${ }^{[27,28]}$ In conclusion, both XPS and TOF-SIMS show Sr enrichment at the LSM 
thin film surface, and the TOF-SIMS furthermore reveals that within a $25 \mathrm{~nm}$ surface layer of the LSM electrode the composition deviates from the bulk LSM composition.
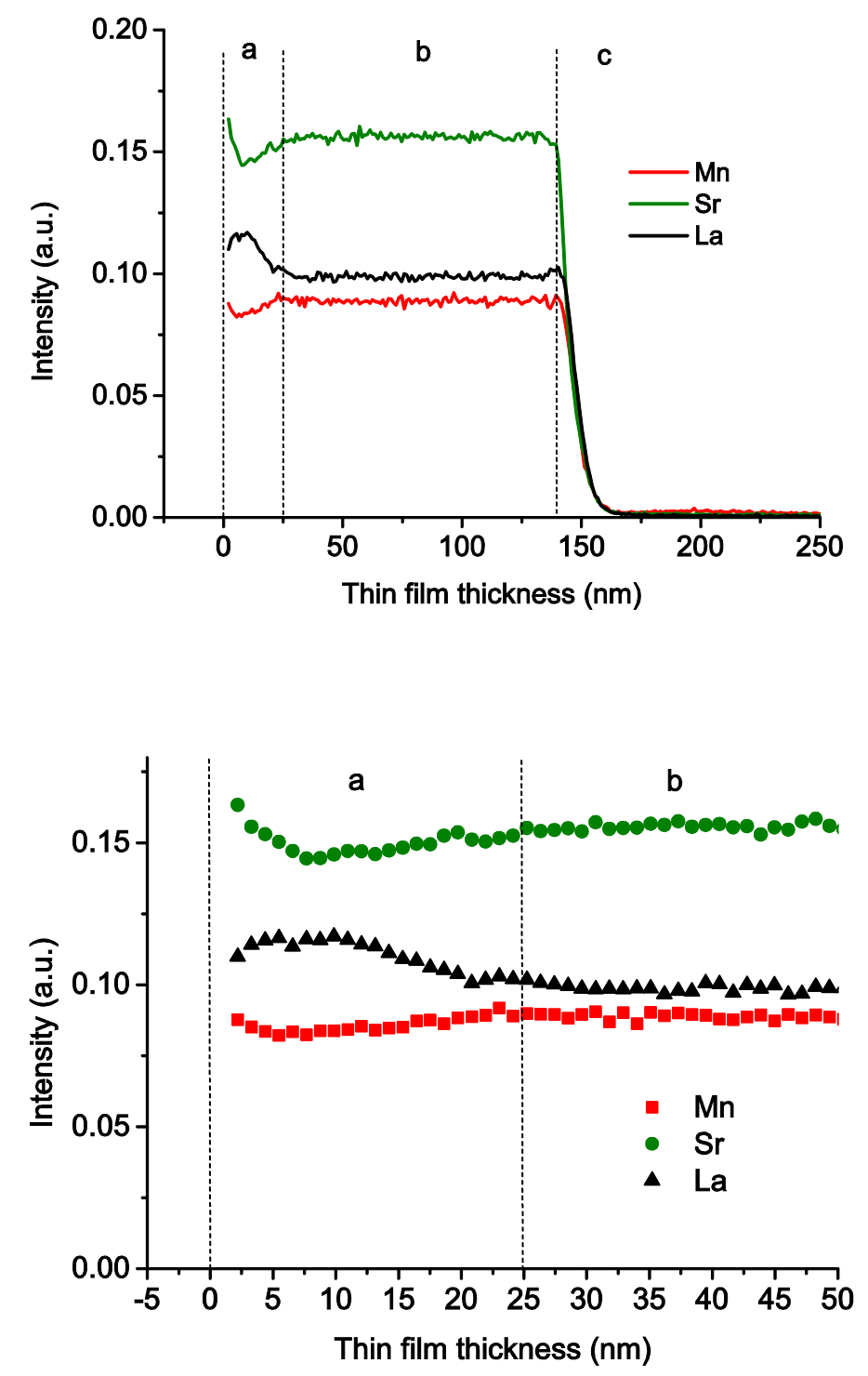

Figure 1. TOF-SIMS depth profile through un-tested LSM thin film, the entire thin film is shown in the top and the $50 \mathrm{~nm}$ closest to the gas-solid interface is shown in the bottom. The letters state the following a) $25 \mathrm{~nm}$ thick LSM surface layer with composition different from the bulk electrode, b) bulk LSM electrode and c) CGO thin film below the LSM electrode. The intensity is proportional to the concentration of the elements. 
Table 1. Ratio between metallic electrode elements in $\left(\mathrm{La}_{0.85} \mathrm{Sr}_{0.15}\right)_{0.9} \mathrm{MnO}_{3 \pm \delta}$ as synthesized and measured at the surface of 4 un-tested LSM thin films by XPS, probing depth 5-10 nm.

\begin{tabular}{lccc}
\hline & As synthesized ratio & Measured ratio & Measured/As synthesized \\
\hline $\mathrm{Sr} / \mathrm{La}$ & 0.176 & $0.27 \pm 0.04$ & 1.53 \\
$\mathrm{Sr} / \mathrm{Mn}$ & 0.135 & $0.41 \pm 0.07$ & 3.04 \\
$\mathrm{La} / \mathrm{Mn}$ & 0.765 & $1.49 \pm 0.15$ & 1.95 \\
$(\mathrm{La}+\mathrm{Sr}) / \mathrm{Mn}$ & 0.9 & $1.91 \pm 0.17$ & 2.12 \\
\hline
\end{tabular}

\subsection{Post-mortem characterization of LSM thin film with BaO}

The LSM thin film electrode with $\mathrm{BaO}$ was characterized by ToF-SIMS after the in operando Raman spectroscopy experiments. The depth profiles for the electrode elements show less well-defined electrode interfaces (Figure 2) compared to the untested LSM-thin electrodes. This difference is ascribed to the sample preparation rather than being a result from the in operando experiments. The depth profile for the Ba shows diffusion of Ba from the surface through the entire LSM electrode. 


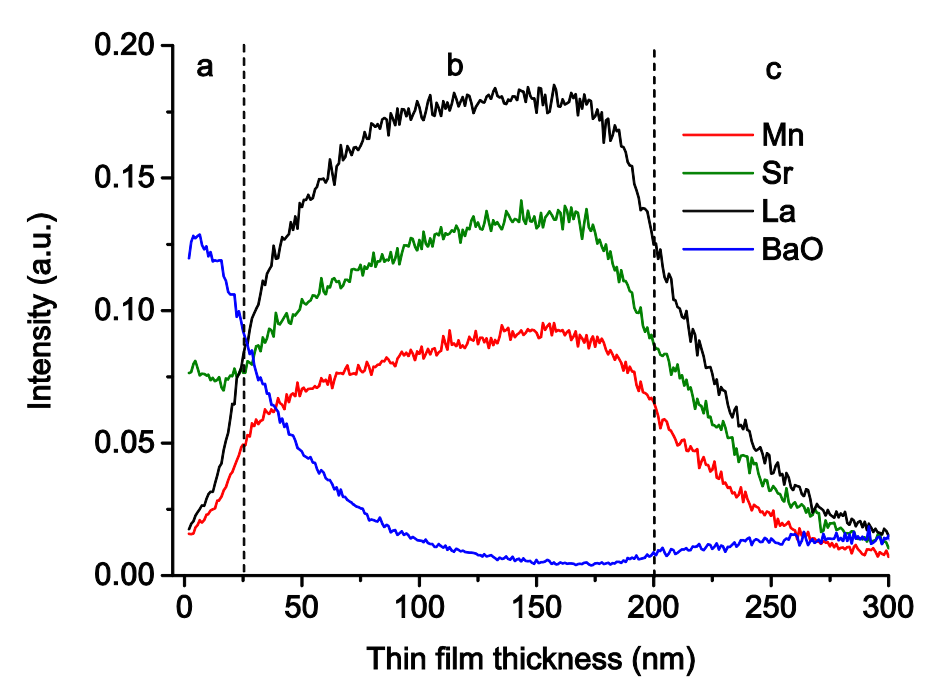

Figure 2. Post mortem ToF-SIMS depth profile through LSM thin film electrode impregnated with $\mathrm{BaO}$. The letters state a) the surface layer, b) the bulk LSM electrode and c) the CGO thin film below the LSM electrode. The Ba depth profile shows diffusion of Ba into the LSM electrode.

\subsection{Presence of $\mathrm{Ba}_{3} \mathrm{Mn}_{2} \mathrm{O}_{8}$ on BaO-infiltrated LSM electrodes}

XRD data collected on $\mathrm{BaO}$ infiltrated porous LSM-CGO electrodes revealed a minor peak at $24.1^{\circ}$ likely due to $\mathrm{BaCO}_{3}$ (ICSD 91888) and three minor peaks in the diffraction pattern at $2 \theta$ locations of $27.7^{\circ}, 31.4^{\circ}$ and $42.2^{\circ}$ (SI-1). These latter features correspond to the three dominant peaks of $\mathrm{Ba}_{3} \mathrm{Mn}_{2} \mathrm{O}_{8}$ (ICSD 280045), one of the few compounds in which $\mathrm{Mn}$ is present in an oxidation state of +5 . This material presumably formed during electrode processing since it was not present during the initial stages of fabrication. As $\mathrm{Ba}_{3} \mathrm{Mn}_{2} \mathrm{O}_{8}$ is not commercially available, $\mathrm{Ba}_{3} \mathrm{Mn}_{2} \mathrm{O}_{8}$ was synthesized according to the procedure described by Weller et al., ${ }^{[29]}$ and characterized by XRD and Raman spectroscopy, the latter revealing two characteristic peaks at $\approx 301 \mathrm{~cm}^{-1}$ and $771 \mathrm{~cm}^{-1}$. Details concerning $\mathrm{Ba}_{3} \mathrm{Mn}_{2} \mathrm{O}_{8}$ synthesis are reported in SI-2 together with XRD and Raman data from the pure compound. 


\section{WILEY-VCH}

\subsection{Raman spectroscopy}

In the following sections, results from the Raman experiments are presented, including spectra recorded on thin model electrodes with and without $\mathrm{BaO}$ deposition. However at first a comparison between the porous LSM-CGO electrode and the thin film electrode is made.

\subsubsection{Reproducibility between porous LSM-CGO electrode and LSM thin film model electrode}

Raman spectra recorded from a porous LSM-CGO electrode (SI-3) were consistent with the results from the thin film electrode with respect to the presence of $\mathrm{Ba}_{3} \mathrm{Mn}_{2} \mathrm{O}_{8}$. In contrast to the thin film electrode, presence of $\mathrm{MnO}_{\mathrm{x}}$ and $\mathrm{BaCO}_{3}$ was not detected in the porous LSMCGO though $\mathrm{BaCO}_{3}$ residues from the impregnation were detected on the edge of the porous electrode, as evidenced by stronger more well-defined $690 \mathrm{~cm}^{-1}$ and $1050 \mathrm{~cm}^{-1}$ peaks, and and likely gave rise to the aforementioned weak $\mathrm{BaCO}_{3}$ signal in the XRD. The presence of $\mathrm{MnO}_{\mathrm{x}}$ and $\mathrm{BaCO}_{3}$ on the pristine thin film electrode and not in the porous electrode is assigned to differences in the preparation method, and does not influence the conclusions drawn on $\mathrm{Ba}_{3} \mathrm{Mn}_{2} \mathrm{O}_{8}$ in this paper. .

2.4.2 Similarities and differences between pure LSM electrodes and electrodes with BaO deposition

Representative in situ Raman spectra collected from thin film LSM electrodes without and with $\mathrm{BaO}$ deposition exposed to 0.1 atm $\mathrm{O}_{2}$ in $\mathrm{Ar}$ at $500{ }^{\circ} \mathrm{C}$ are shown in Figure 3. Spectra recorded prior to polarization show clearly the compositional differences between electrodes. The most distinct vibrational feature for the pure LSM thin film electrode is a broad peak at $610 \mathrm{~cm}^{-1}$. Vibrational modes of both $\mathrm{YSZ}^{[30,31]}$ and $\mathrm{MnO}_{\mathrm{x}}{ }^{[32,33]}$ species are found in this region. For cells with thin film electrodes, this feature may therefore arise from $\mathrm{MnO}_{\mathrm{x}}$ on the electrode surface/within the electrode and/or from the YSZ substrate below the electrode. Cells with the screen printed LSM-CGO electrode (SI-4) did not contain YSZ but showed a 


\section{WILEY-VCH}

similar peak around $610 \mathrm{~cm}^{-1}$ that can result only from $\mathrm{MnO}_{\mathrm{x}}$ species. The literature reports some discrepancy on peak assignments for the vibrational Raman modes of $\mathrm{MnO}_{\mathrm{x}}$ species. ${ }^{[32 \text {, }}$

33] Some of this uncertainty can be attributed to material changes induced by exposure to high intensity fields including laser light. ${ }^{[32,34]}$ Furthermore, the different phases of $\mathrm{MnO}_{\mathrm{x}}$ all have vibrational features between 570-690 $\mathrm{cm}^{-1}$. Given these considerations and a preponderance of evidence in the literature, the $610 \mathrm{~cm}^{-1}$ peak is assigned tentatively to $\mathrm{MnO}_{2 .}{ }^{[32],[35,36]}$ This assignment is also consistent with XPS results by Backhaus-Ricoult et al. that showed Mn in an oxidation state of +4 on the unpolarised LSM surface. ${ }^{[11]}$

In contrast to the pure LSM thin film electrode, the $\mathrm{BaO}$ modified LSM thin film electrode exhibits several sharper bands in the Raman spectrum. Two features are observed consistently at $306 \mathrm{~cm}^{-1}$ and $773 \mathrm{~cm}^{-1}$ on the electrodes with $\mathrm{BaO}$. The $306 \mathrm{~cm}^{-1}$ and $773 \mathrm{~cm}^{-1}$ peaks are assigned to a $\mathrm{Ba}_{3} \mathrm{Mn}_{2} \mathrm{O}_{8}$ secondary phase and are discussed in more detail below. In addition to these features, a peak at $1051 \mathrm{~cm}^{-1}$ was observed and the intensity of this peak varied strongly with the position on the sample. Since $\mathrm{MnO}$ has peak at $1050 \mathrm{~cm}^{-1}{ }^{[37]}$ and $\mathrm{BaCO}_{3}$ a peak at $1052 \mathrm{~cm}^{-1}[38]$ the observed peak is tentatively assigned to one of these two species. 


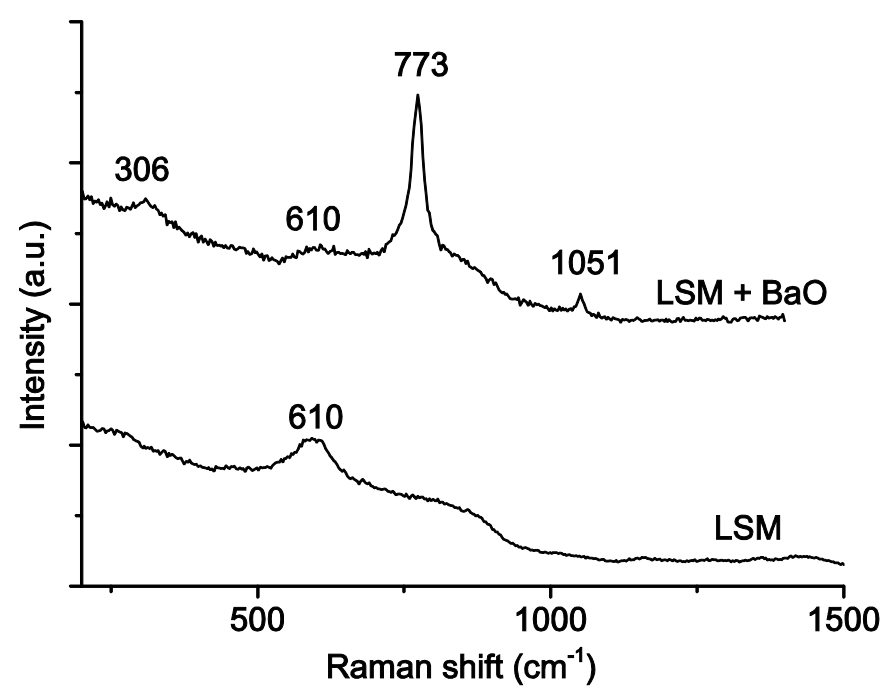

Figure 3. Representative Raman spectra recorded on a LSM thin film electrode with and without $\mathrm{BaO}$ infiltration at $500{ }^{\circ} \mathrm{C}$ in $10 \%$ oxygen flow. The top spectrum is displaced vertically to facilitate comparison.

Table 2 summarizes assignments for materials observed in the Raman spectra during the experiments on the thin films samples. All peaks were not present simultaneously, but depended on the sample and experimental conditions.

Table 2 Overview of all peaks observed in the Raman spectra recorded on the thin film samples; note all peaks may not be observed simultaneously

\begin{tabular}{lll}
\hline Raman shift & Assignment & Reference \\
{$\left[\mathrm{cm}^{-1}\right]$} & & \\
\hline 306 & $\mathrm{Ba}_{3} \mathrm{Mn}_{2} \mathrm{O}_{8}$ & This work, see SI-2 \\
610 & $\mathrm{YSZ}$ & {$[30,31]$} \\
610 (broad and weak) & $\mathrm{MnO}_{x}$, most likely $\mathrm{MnO}_{2}$ & {$[33,35,39]$} \\
644 & $\mathrm{MnO}_{x}$, most likelyMn $\mathrm{MO}_{4}$ & {$[32,33]$}
\end{tabular}




\begin{tabular}{lll}
662 & $\mathrm{MnO}_{x}$, most likely $\mathrm{Mn}_{2} \mathrm{O}_{3}$ & \\
690 & $\mathrm{BaCO}_{3}$ & {$[33]$} \\
771 & $\mathrm{Ba}_{3} \mathrm{Mn}_{2} \mathrm{O}_{8}$ & This wo] work, see SI-2 \\
1050 & $\mathrm{MnO}$ & {$[37]$} \\
1052 & $\mathrm{BaCO}_{3}$ & {$[38]$} \\
\hline
\end{tabular}

\subsubsection{Effect of applied potential on electrode surface composition}

In operando Raman measurements were performed to investigate how electrode composition changed as a function of applied potential and temperature. Experimental parameters are summarized in Table 3. With two exceptions, measurement series were conducted at least twice for each combination of parameters to confirm the reproducibility of the results. In general, the chronoamperometry curves recorded during cathodic polarizations showed a small deactivation during the first $\approx 600 \mathrm{~s}$, resulting in a $10-20 \%$ decrease in the current density, (see SI-4). After these initial changes, the current density stayed stable indicating the electrode did not suffer further degradation during the experiments.

Table 3. The parameters used during the in operando Raman characterization

\begin{tabular}{lc}
\hline Parameter & Values \\
\hline Atmosphere & 0.1 atm $\mathrm{O}_{2}$ in $\mathrm{Ar}$ \\
Temperature & $300{ }^{\circ} \mathrm{C}, 500{ }^{\circ} \mathrm{C}$ \\
Applied voltage & $\mathrm{OCV},-1 \mathrm{~V},+1 \mathrm{~V}$ \\
\hline
\end{tabular}

The following section describes how the chemical species detected with Raman spectroscopy were influenced by operational conditions. Raman spectra recorded at $500{ }^{\circ} \mathrm{C}$ prior to, during and after cathodic polarization of $-1 \mathrm{~V}$ are shown in Figure 4a) and Figure 4b) together with 


\section{WILEY-VCH}

the corresponding changes in selected peak intensities plotted in Figure 4c). Finally, Figure 5 shows a peak intensity plot for a similar experiment conducted at $500{ }^{\circ} \mathrm{C}$; however, in this case the cell polarization was switched to $+1 \mathrm{~V}$ immediately after the $-1 \mathrm{~V}$ polarization.

Electrodes exhibited consistent qualitative behaviors with respect to polarization at $300{ }^{\circ} \mathrm{C}$ and $500{ }^{\circ} \mathrm{C}$. Spectra from the electrode operating at $300{ }^{\circ} \mathrm{C}$ are reported in SI-5. 

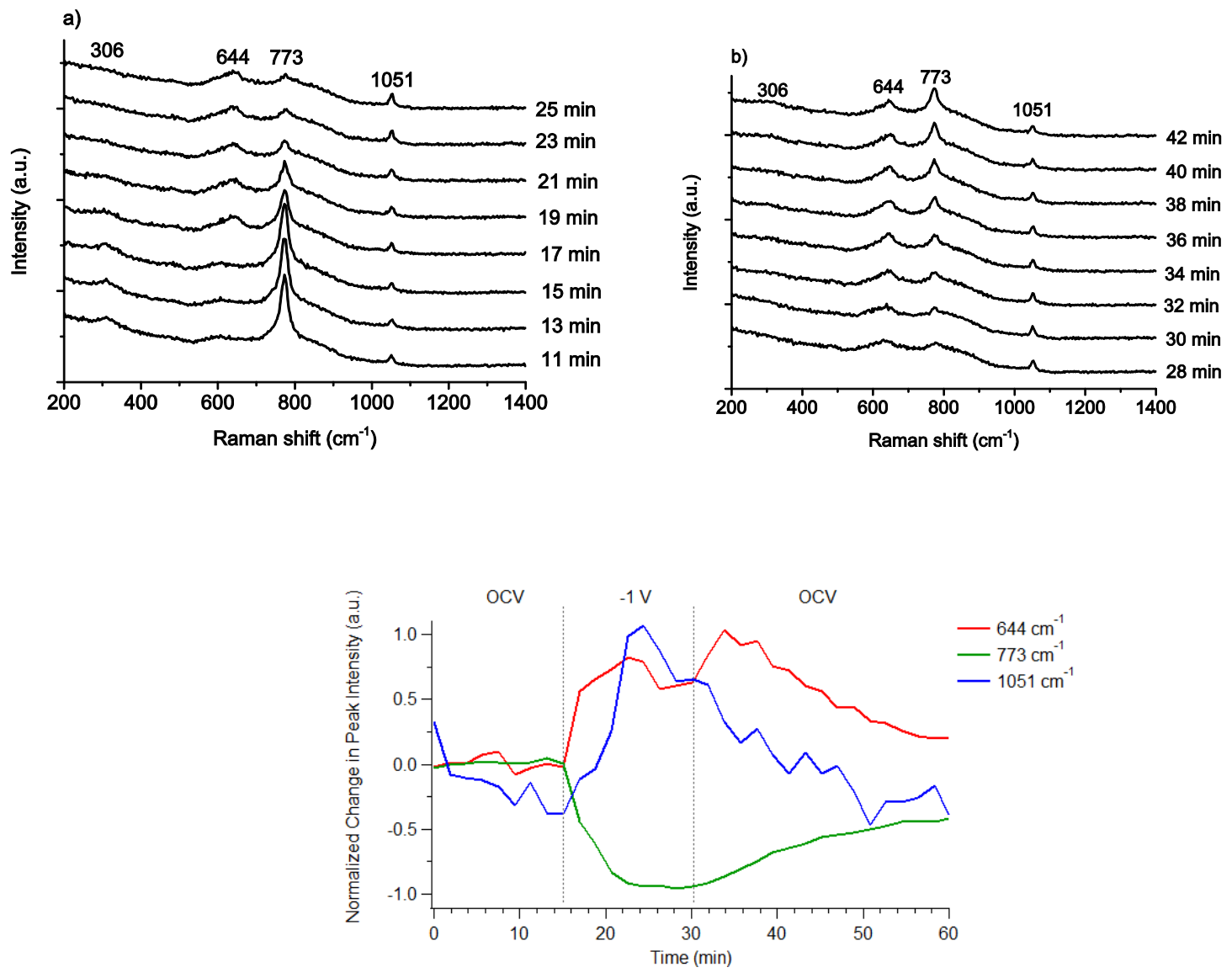

Figure 4. Raman spectra on $\mathrm{BaO}$ infiltrated LSM thin film electrode at $500{ }^{\circ} \mathrm{C}$ with $10 \% \mathrm{O}_{2}$ :

a) before and during the onset of $-1 \mathrm{~V}$ b) at $-1 \mathrm{~V}$ followed by OCV and c) the normalized peak intensity plot for the data set shown in a) and b).

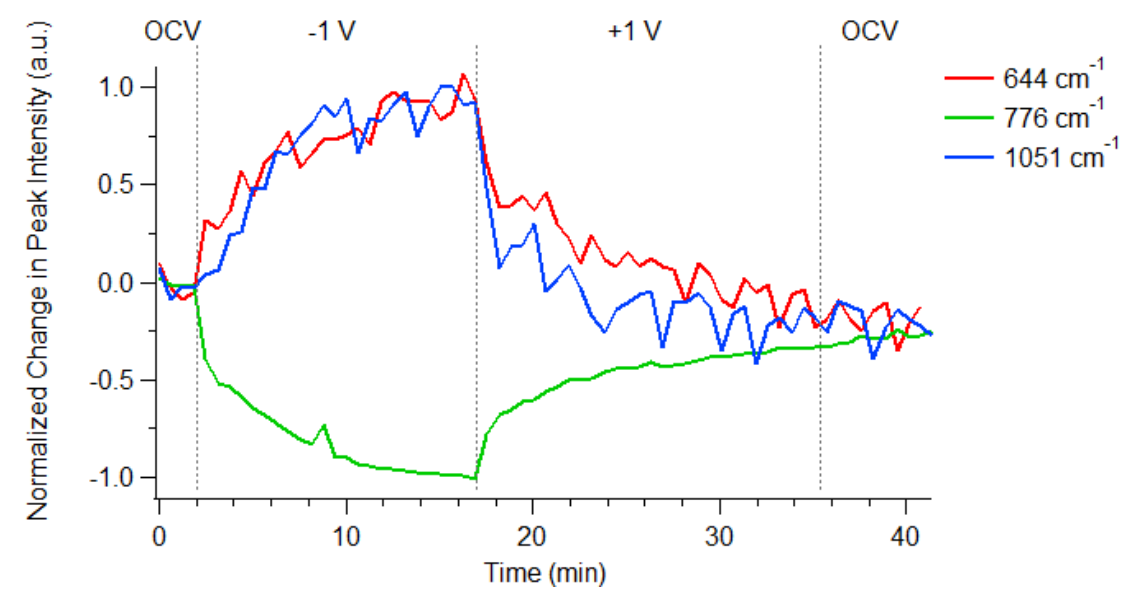

Figure 5. Peak intensity plot from Raman spectra on $\mathrm{BaO}$ infiltrated LSM thin film electrode at $500{ }^{\circ} \mathrm{C}$ with $10 \% \mathrm{O}_{2}$ during $-1 \mathrm{~V}$ polarization followed immediately by $+1 \mathrm{~V}$ polarization. 


\section{WILEY-VCH}

$\mathrm{Ba}_{3} \mathrm{Mn}_{2} \mathrm{O}_{8}$ : The formation and decomposition of $\mathrm{Ba}_{3} \mathrm{Mn}_{2} \mathrm{O}_{8}$ was characterized by reversible increases or decreases, respectively, of the $306 \mathrm{~cm}^{-1}$ and $773 \mathrm{~cm}^{-1}$ peak intensities. Raman spectra showed that in a 0.1 atm $\mathrm{O}_{2}$ environment, the $\mathrm{Ba}_{3} \mathrm{Mn}_{2} \mathrm{O}_{8}$ vibrational band intensity diminished during cathodic polarization at $-1 \mathrm{~V}$ (Figure 4 and Figure 5) and increased to an asymptotic limit during anodic polarization at $+1 \mathrm{~V}$ (Figure 5). Similarly, when the cell was held at OCV after cathodic polarization, the $\mathrm{Ba}_{3} \mathrm{Mn}_{2} \mathrm{O}_{8}$ peak intensities increased (Figure 4c), but at a slower rate compared to the increase observed during anodic polarization. Taken together, these observations show that the amount of the $\mathrm{Ba}_{3} \mathrm{Mn}_{2} \mathrm{O}_{8}$ secondary phase in an infiltrated electrode depends strongly on the applied potential, in this case ranging from almost full decomposition at cathodic polarization to full regeneration at OCV or anodic polarization.

$\mathrm{MnO}_{\mathrm{x}}$ : In addition to the $\mathrm{MnO}_{2}$ peak at $610 \mathrm{~cm}^{-1}$, a broad vibrational band was observed at approximately $644 \mathrm{~cm}^{-1}$. Contrary to the behavior observed for the $773 \mathrm{~cm}^{-1}$ feature assigned to $\mathrm{Ba}_{3} \mathrm{Mn}_{2} \mathrm{O}_{8}$, the signal at $644 \mathrm{~cm}^{-1}$ increased upon cathodic polarization of the electrode (Figure 4 and Figure 5). This feature is most likely a signature of $\mathrm{Mn}_{3} \mathrm{O}_{4}$ given literature reports of a dominant band at $650 \mathrm{~cm}^{-1}$ in spectra collected at room temperature. ${ }^{[32,33]}$ Furthermore, these prior studies have also shown that $\mathrm{MnO}_{2}$ and $\mathrm{Mn}_{2} \mathrm{O}_{3}$ may be converted into $\mathrm{Mn}_{3} \mathrm{O}_{4}$ due to localized heating from the laser excitation source used for the Raman measurements. ${ }^{[32-34,41]}$ In Figure 4c and Figure 5 the formation of $\mathrm{Mn}_{3} \mathrm{O}_{4}$ is anticorrelated with the loss of $\mathrm{Ba}_{3} \mathrm{Mn}_{2} \mathrm{O}_{8}$. These results suggest that $\mathrm{Ba}_{3} \mathrm{Mn}_{2} \mathrm{O}_{8}$ decomposition is a dominant source for the observed $\mathrm{Mn}_{3} \mathrm{O}_{4}$ formation. The $\mathrm{Mn}_{3} \mathrm{O}_{4}$ expulsion from the LSM electrode itself during cathodic polarization cannot be excluded either, since the peak intensity plots occasionally show an increase in the $\mathrm{Mn}_{3} \mathrm{O}_{4}$ occurring faster than the decrease in the $\mathrm{Ba}_{3} \mathrm{Mn}_{2} \mathrm{O}_{8}$ signal (see SI-6). We propose that under reducing conditions, the $\mathrm{Ba}_{3} \mathrm{Mn}_{2} \mathrm{O}_{8}$ (where $\mathrm{Mn}$ is in a +5 oxidation state) decomposes into $\mathrm{Mn}_{3} \mathrm{O}_{4}$ (with mixed $\mathrm{Mn}^{2+} / \mathrm{Mn}^{3+}$ character). The resulting Ba-containing material eluded detection in these experiments, and in 


\section{WILEY-VCH}

this connection it is noted the absence of $\mathrm{CO}_{2}$ in the gas flow make generation of $\mathrm{BaCO}_{3}$ unlikely. A change in the $1051 \mathrm{~cm}^{-1}$ peak was observed upon polarization as the peak increased during cathodic polarization and decreased during subsequent OCV and anodic polarization (Figure 4 and Figure 5). However, this increase in intensity was only observable when the $1051 \mathrm{~cm}^{-1}$ was either small or non-existant prior to the polarization. If a large, dominant peak at $1051 \mathrm{~cm}^{-1}$ was present in spectra before the polarization, no effect of cathodic polarization was observed, yet a decrease was still observed during anodic polarization (see SI-5). This result is explained by the coincidence between the $\mathrm{BaCO}_{3}$ peak at $1052 \mathrm{~cm}^{-1}$ and the $\mathrm{MnO}$ peak at $1050 \mathrm{~cm}^{-1}$, as the strong $\mathrm{BaCO}_{3}$ peak occasionally overshadowed changes in the weak $\mathrm{MnO}$ peak. The $\mathrm{BaCO}_{3}$ was not affected during cathodic polarization, but partly oxidized during anodic polarization. The $\mathrm{MnO}$ was formed during cathodic polarization and removed during anodic polarization. The correlation between the polarization induced changes in the $\mathrm{MnO}_{\mathrm{x}}$ species and the $\mathrm{Ba}_{3} \mathrm{Mn}_{2} \mathrm{O}_{8}$ will be discussed further on the "Discussion" section.

The transformations observed with cathodic polarizations were reversible. Once the cathodic polarization was removed, the vibrational signature for $\mathrm{Ba}_{3} \mathrm{Mn}_{2} \mathrm{O}_{8}$ began to reappear (Figure $4 \mathrm{~b}$ and Figure 4c), eventually approaching its original intensity prior to the $-1 \mathrm{~V}$ polarization. Changing the bias immediately from $-1 \mathrm{~V}$ to $+1 \mathrm{~V}$ accelerated the regeneration of $\mathrm{Ba}_{3} \mathrm{Mn}_{2} \mathrm{O}_{8}$ (Figure 5). Interestingly, when the cathodic polarization (-1V) was changed to OCV, the $\mathrm{Ba}_{3} \mathrm{Mn}_{2} \mathrm{O}_{8}$ began to grow back immediately, albeit slowly, while the $\mathrm{Mn}_{3} \mathrm{O}_{4}$ signal continued to increase for several minutes before eventually returning to pre-cathodic polarization levels (Figure 4c). The continued growth of the $\mathrm{Mn}_{3} \mathrm{O}_{4}$ signal after the cathodic polarization was removed is ascribed to re-oxidation of $\mathrm{MnO}$ and is discussed below.

Finally, we note that all of the spectroscopic measurements show that material changes happen on the order of minutes or tens of minutes when the cell is polarized at $300^{\circ} \mathrm{C}$ or $500{ }^{\circ} \mathrm{C}$, with the most dramatic material changes occurring within the first 5 minutes. Thus, 


\section{WILEY-VCH}

ex situ techniques or in situ measurements without sufficient temporal resolution will not be able to resolve compositional changes occurring in these high temperature materials during operation.

\section{Discussion}

\subsection{Electrode surface composition at OCV conditions}

$\mathrm{BaO}$ infiltration of LSM electrodes has in previous work, based on electrochemical impedance spectroscopy at OCV conditions, been reported to cause a significant decrease in the polarization resistance. ${ }^{[21,24,25]}$ The aim in the present study is to investigate the reason for this decrease, which, depending on reaction conditions and sample preparation, may be as large as an order of magnitude. ${ }^{[21,24,25]}$ Raman spectroscopy performed with electrodes at OCV revealed the presence of $\mathrm{Ba}_{3} \mathrm{Mn}_{2} \mathrm{O}_{8}$ on the $\mathrm{BaO}$ infiltrated LSM electrodes to be the only consistent difference between infiltrated and non-filtrated electrodes. For this reason $\mathrm{Ba}_{3} \mathrm{Mn}_{2} \mathrm{O}_{8}$ is suggested to cause the reduced polarization resistance at OCV observed when LSM electrodes are infiltrated with $\mathrm{BaO}$. Unfortunately there are to the best of the author's knowledge no reports in literature on the electrical properties of $\mathrm{Ba}_{3} \mathrm{Mn}_{2} \mathrm{O}_{8}$. However, work described by Roos et al. ${ }^{[42]}$ may provide insight into the electrical properties of $\mathrm{Ba}_{3} \mathrm{Mn}_{2} \mathrm{O}_{8}$ since Roos et al. explain manganese ions in tetrahedral coordination as in $\mathrm{Ba}_{3} \mathrm{Mn}_{2} \mathrm{O}_{8}$ can easily change from $\mathrm{Mn}^{5+}$ to $\mathrm{Mn}^{4+}$ and from $\mathrm{Mn}^{4+}$ to $\mathrm{Mn}^{3+}$, which may contribute to the observed enhancement of the electrode's electrocatalytic properties. The suggestion that $\mathrm{Ba}_{3} \mathrm{Mn}_{2} \mathrm{O}_{8}$ causes the reduced polarization resistance at OCV is made with the reservation that for each reporting in the literature, both the amount of Ba infiltrate and the LSM stoichiometry play a role in secondary phase formation and the possible formation of $\mathrm{BaCO}_{3}$, which may also influence the electrocatalytic properties ${ }^{[24]}$. However, regardless of the impregnation method and materials choice, electrodes in a real application are subjected to 


\section{WILEY-VCH}

electrical polarization, for which reason the effect of cathodic and anodic polarization on the $\mathrm{BaO}$ infiltrated LSM electrode was investigated in this study.

\subsection{Electrical polarization and electrode surface composition}

The in operando Raman spectra presented in Figure 4 and Figure 5 demonstrate clearly that the surfaces of a BaO-infiltrated LSM-electrode are dynamic and significantly affected by an applied polarization. The discussion below focuses on how the dominant species on the electrode surface, $\mathrm{Ba}_{3} \mathrm{Mn}_{2} \mathrm{O}_{8}$ and $\mathrm{MnO}_{\mathrm{x}}$, are affected by the applied reaction conditions. 3.2.1Ba $\mathrm{Mn}_{2} \mathrm{O}_{8}$ : Under 0.1 atm $\mathrm{O}_{2}$ in $\mathrm{Ar}, \mathrm{Ba}_{3} \mathrm{Mn}_{2} \mathrm{O}_{8}$ showed a strong dependence on the applied electrical polarization where cathodic polarization promoted decomposition and anodic polarization promoted the regeneration of $\mathrm{Ba}_{3} \mathrm{Mn}_{2} \mathrm{O}_{8}$ on the LSM electrode. Cathodic polarization has the same effect on LSM electrodes as very low oxygen partial pressures, a condition that promotes the formation of oxygen vacancies. ${ }^{[4]}$ Continued exposure to high cathodic polarization conditions and/or low the oxygen partial pressure ultimately leads to decomposition of LSM electrodes ${ }^{[44-46]}$ and will also decompose complex oxides like $\mathrm{Ba}_{3} \mathrm{Mn}_{2} \mathrm{O}_{8}$. The Ba-Mn-O diagram ${ }^{[47]}$ (Figure 6) shows that the total oxide content in the $\mathrm{Ba}_{3} \mathrm{Mn}_{2} \mathrm{O}_{8}$ only needs to decrease $4 \%$ for the material to transform into a different stoichiometric compound. Furthermore, the diagram reveals that if the oxide content is reduced by $4-5 \%$ a region is reached in which several Ba-Mn-O and Mn-O compounds can coexist, which corresponds well with the increase in different $\mathrm{MnO}_{\mathrm{x}}$ species observed on the electrode surface during cathodic polarization in this study. 


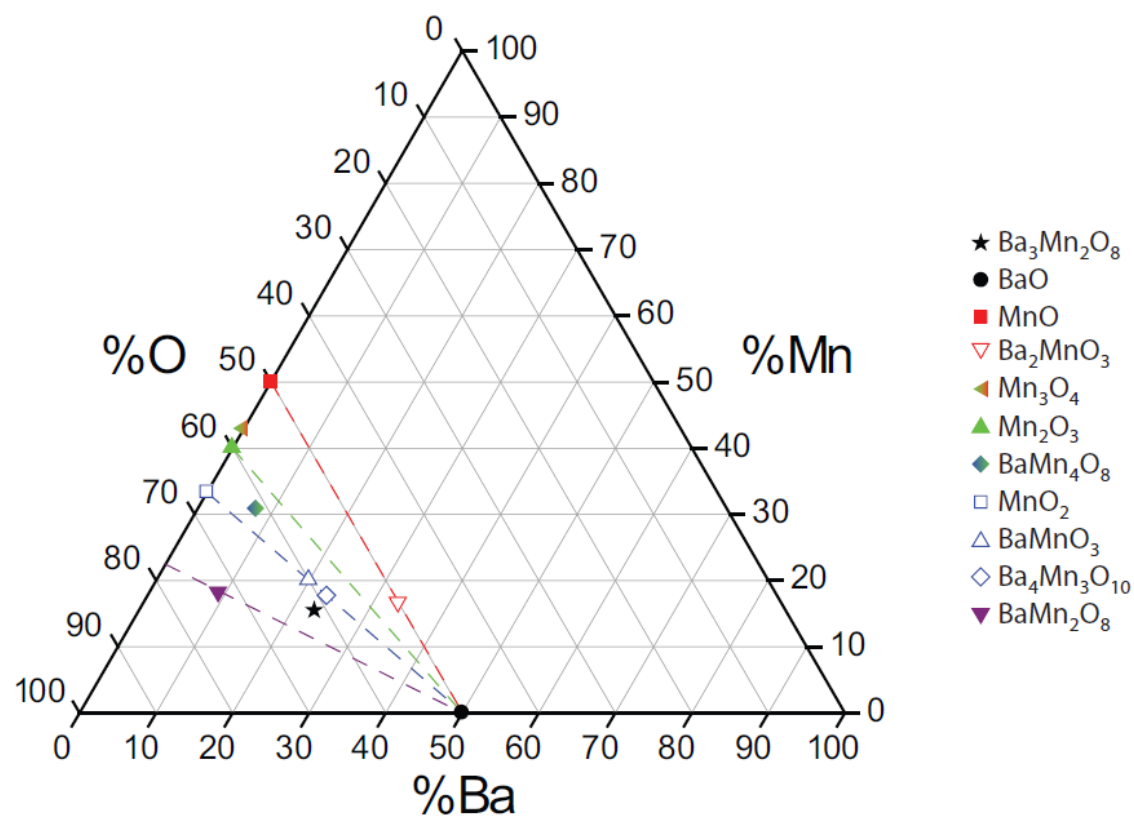

Figure 6. Ba-Mn-O ternary diagram showing $\mathrm{Ba}_{3} \mathrm{Mn}_{2} \mathrm{O}_{8}$ (black star) and other phases.

Compounds with the Mn Valence of +2 (red) +3 (green) , +4(blue) and +7 (purple) are grouped by color and connected by dashed lines, while compounds with mixed Mn valence have a gradient between the colors representing the two different valences. The diagram is reprinted from the dissertation thesis of Eric C. Samulon ${ }^{[47]}$.

3.2.2 $\mathrm{MnO}_{x}$ : The in operando Raman spectra show that the amount of $\mathrm{Mn}_{3} \mathrm{O}_{4}$ on the electrode surface increased significantly during cathodic polarization and decreased during anodic polarization. We propose that the dominant source of the $\mathrm{Mn}_{3} \mathrm{O}_{4}$ is $\mathrm{Ba}_{3} \mathrm{Mn}_{2} \mathrm{O}_{8}$ given that during the majority of the polarizations the intensity of the $\mathrm{Ba}_{3} \mathrm{Mn}_{2} \mathrm{O}_{8}$ and the $\mathrm{Mn}_{3} \mathrm{O}_{4}$ Raman signal appear directly anti-correlated. Expulsion of $\mathrm{Mn}_{3} \mathrm{O}_{4}$ from the LSM electrode itself during cathodic polarization may also be a minor source for $\mathrm{Mn}_{3} \mathrm{O}_{4}$, as expulsion of $\mathrm{Mn}_{3} \mathrm{O}_{4}$ from LSM previously has been observed ex situ by XRD on LSM samples sintered at low oxygen partial pressure $\left(\mathrm{pO}_{2}=10^{-6}\right.$ atm $) .{ }^{[46]}$ Furthermore expulsion of $\mathrm{MnO} / \mathrm{Mn}_{3} \mathrm{O}_{4}$ has been reported on LSM and lanthanum manganite electrodes during cyclic voltammetry. ${ }^{[45]}$ Ex situ 


\section{WILEY-VCH}

ToF-SIMS studies of LSM microelectrodes have also revealed a strong, irreversible redistribution of the $\mathrm{Mn}$ from the electrode onto the electrolyte after electrical polarization. ${ }^{[26]}$ In situ studies of manganese redistribution on LSM electrodes are scarce. Among the few literature reports is work by Backhaus-Ricoult et al., who detected polarization induced reduction and migration of Mn-species onto the electrolyte by XPS under conditions approximating those employed in solid oxide fuel cell systems. ${ }^{[11]}$ Results from the in operando Raman measurements generally agree with findings from the aforementioned studies in terms of the capability of a cathodic polarization to re-distribute Mn in/on the LSM electrode. However, the Raman data imply $\mathrm{Mn}_{3} \mathrm{O}_{4}$ enrichment during cathodic polarization whereas the in situ XPS study showed Mn depletion at the electrode surface during cathodic polarization. ${ }^{[11]}$ The discrepancy is likely explained by a combination of: (1) the presence of $\mathrm{Ba}_{3} \mathrm{Mn}_{2} \mathrm{O}_{8}$ that acts as a $\mathrm{Mn}_{3} \mathrm{O}_{4}$ source in this work, (2) Backhaus-Ricoult using stoichiometric $\mathrm{La}_{0.8} \mathrm{Sr}_{0.2} \mathrm{MnO}_{3}{ }^{[11]}$ while the present study employed A-site deficient $\left(\mathrm{La}_{0.85} \mathrm{Sr}_{0.15}\right)_{0.9} \mathrm{MnO}_{3 \pm \delta}$, and/or (3) diffusion of Ba-ions into the LSM, as evident from the ToFSIMS characterization (Figure 2) altering cation segregation mechanism(s).

One interesting observation of $\mathrm{Mn}_{3} \mathrm{O}_{4}$ observed in operando considers the behavior of $\mathrm{Mn}_{3} \mathrm{O}_{4}$ at OCV following cathodic polarization. After the Raman signal from $\mathrm{Mn}_{3} \mathrm{O}_{4}$ increases and stabilizes during cathodic polarization, the $\mathrm{Mn}_{3} \mathrm{O}_{4}$ increases even further during the first 3-5 min at OCV after the polarization has been removed at $500{ }^{\circ} \mathrm{C}$ (Figure 4). These observations appear contradictory, namely that applying a cathodic polarization causes an increase in the $\mathrm{Mn}_{3} \mathrm{O}_{4}$ signal, and the removal of the cathodic polarization is accompanied by a $\mathrm{Mn}_{3} \mathrm{O}_{4}$ signal intensity that increases even further. A plausible explanation of this phenomenon hinges on the labile nature of $\mathrm{Mn}^{\mathrm{n}+}$. In $\mathrm{Ba}_{3} \mathrm{Mn}_{2} \mathrm{O}_{8}$, Mn has a formal oxidation state of 5+. Under cathodic polarization of $-1 \mathrm{~V}$, Raman spectra show that reduced forms of $\mathrm{Mn}$ (i.e. $\mathrm{Mn}^{3+}$ and $\mathrm{Mn}^{2+}$ ) become more prevalent, given the growth of vibrational signatures at $644 \mathrm{~cm}^{-1}\left(\mathrm{Mn}_{3} \mathrm{O}_{4}\right)$ 


\section{WILEY-VCH}

and $1050 \mathrm{~cm}^{-1}(\mathrm{MnO})$. When the bias is removed or reversed, thermodynamic considerations will once again favor more oxidized forms of Mn, leading eventually to the fully recovered amount of $\mathrm{Mn}^{5+}$ in $\mathrm{Ba}_{3} \mathrm{Mn}_{2} \mathrm{O}_{8}$. Given the availability of mobile oxide ions, we propose that as MnO begins to oxidize, $\mathrm{Mn}_{3} \mathrm{O}_{4}$ forms as an intermediate species on a path that ultimately results in $\mathrm{Ba}_{3} \mathrm{Mn}_{2} \mathrm{O}_{8}$ and accounts for the growth in the $644 \mathrm{~cm}^{-1}$ Raman band after the cell polarization returns to $\mathrm{OCV}$ from $-1 \mathrm{~V}$. When the bias is reversed from $-1 \mathrm{~V}$ to $+1 \mathrm{~V}$, the kinetics of such a transformation would simply be too fast for experiments to report the $\mathrm{Mn}_{3} \mathrm{O}_{4}$ intermediate growth. This hypothesis is supported by a weak decrease in $\mathrm{Mn}_{3} \mathrm{O}_{4}$ signal at the end of the cathodic polarization (Figure 4c).

Finally, an additional observation associated with $\mathrm{MnO}_{\mathrm{x}}$ segregation on the electrode surface is that the segregation was only observed on LSM electrodes with $\mathrm{BaO}$. A number of LSM thin film electrodes without $\mathrm{BaO}$ deposition were subjected to various treatments, including higher temperatures $\left(700^{\circ} \mathrm{C}\right)$ and stronger polarizations $(-2.5 \mathrm{~V})$ than those applied to the $\mathrm{BaO}$ modified electrodes. ${ }^{[48]}$ Despite these more extreme conditions, an increase in the amount of $\mathrm{Mn}_{3} \mathrm{O}_{4}$ was not observed with Raman spectroscopy during any of the polarizations ${ }^{[48]}$. The fact that changes in $\mathrm{Mn}_{3} \mathrm{O}_{4}$ were not observed on the pure LSM electrodes suggests that the $\mathrm{Ba}_{3} \mathrm{Mn}_{2} \mathrm{O}_{8}$ secondary phase is a dominant source for $\mathrm{Mn}_{3} \mathrm{O}_{4}$ formation, although Ba diffusion into the LSM electrode (Figure 2) can have influenced Mn segregation. Regarding the amount of Ba, which can be accommodated in LSM, experiments have shown that lanthanum manganates are stable with up to $40 \%$ substitution of Ba on the La site. ${ }^{[49]}$ However, a recent study of lanthanum manganite thin films has shown that the maximum substitution level is strongly dependent on temperature and oxygen partial pressure. ${ }^{[50]}$

The $\mathrm{Ba}_{3} \mathrm{Mn}_{2} \mathrm{O}_{8}$ secondary phase on LSM electrodes infiltrated with $\mathrm{BaO}$ was most likely formed via a reaction with excess $\mathrm{MnO}_{\mathrm{x}}$ in the electrode. The behavior of this secondary 
phase and of $\mathrm{MnO}_{\mathrm{x}}$ phases during polarization has been discussed above, and in Eq. (1)-(3) the proposed cathode reactions are summarized.

$$
\begin{aligned}
& 14 e^{-}+3 \mathrm{Ba}_{3} \mathrm{Mn}_{2} \mathrm{O}_{8} \rightarrow 2 \mathrm{Mn}_{3} \mathrm{O}_{4}+9 \mathrm{BaO}+7 \mathrm{O}^{2-} \\
& \mathrm{LSM}_{\mathrm{ox}}+2 e^{-} \rightarrow \mathrm{LSM}_{\mathrm{red}}+\mathrm{Mn}_{3} \mathrm{O}_{4}+\mathrm{MnO}+\mathrm{O}^{2-} \\
& \mathrm{Mn}_{3} \mathrm{O}_{4}+2 e^{-} \rightarrow 3 \mathrm{MnO}+\mathrm{O}^{2-}
\end{aligned}
$$

So far it has been suggested that $\mathrm{Ba}_{3} \mathrm{Mn}_{2} \mathrm{O}_{8}$ is responsible for the reduced polarization resistance observed on the $\mathrm{BaO}$ infiltrated LSM electrodes at OCV conditions. Furthermore the removal of $\mathrm{Ba}_{3} \mathrm{Mn}_{2} \mathrm{O}_{8}$ and the associated changes in the electrode surface composition during cathodic polarization has been thoroughly discussed. Still unresolved is how these compositional changes during polarization influence electrode performance. A common issue in LSM electrodes and other perovskite based electrodes is passivation of the electrode surface due to segregation of $\mathrm{Sr}$ and impurities to the surface. ${ }^{[28]}$ We suggest that reduction of $\mathrm{Ba}_{3} \mathrm{Mn}_{2} \mathrm{O}_{8}$ releasing $\mathrm{Mn}_{3} \mathrm{O}_{4}$ and $\mathrm{MnO}$ onto the electrode surface will increase the electrochemical activity. This suggestion is based on literature reportings showing decreased

polarization resistance in oxygen atmospheres on LSM electrodes infiltrated with $\mathrm{MnO}_{\mathrm{x}}{ }^{[51,52]}$ or Pt-YSZ electrodes modified with Mn-species ${ }^{[53]}$. Since very limited reports are made on the electrocatalytic properties of $\mathrm{MnO}_{\mathrm{x}}$, further experiments are needed to test the hypothesis that the release of $\mathrm{Mn}_{3} \mathrm{O}_{4}$ and/or $\mathrm{MnO}$ one the electrode surface increases the electrochemical activity of the $\mathrm{BaO}$ infiltrated electrodes during operation.

\section{Conclusion}

The experiments on $\mathrm{BaO}$ modified LSM electrodes described in this work were conducted to explore how the addition of $\mathrm{BaO}$ affects the LSM electrodes' electrocatalytic properties, particularly as an $\mathrm{O}_{2}$ reduction catalyst. The enhanced electrocatalytic properties caused by 


\section{WILEY-VCH}

the $\mathrm{BaO}$ modification is, based on this work, at OCV conditions ascribed to formation of a secondary $\mathrm{Ba}_{3} \mathrm{Mn}_{2} \mathrm{O}_{8}$ phase. During cathodic polarization a significant redistribution of elements in the electrode surface takes place, as the $\mathrm{Ba}_{3} \mathrm{Mn}_{2} \mathrm{O}_{8}$ phase decomposes and $\mathrm{MnO}_{\mathrm{x}}$ species accumulates in the electrode surface. The redistributions are reversible with polarization, thus the electrode returns to the original state when polarized in the anodic direction or returned to OCV. These reversible changes illustrate that element or material specific techniques must be applied in operando, to envisage the active state during operation of an infiltrated LSM electrode, or any other solid electrode prepared infiltration. Knowing the exact electrode composition during operation is a crucial prerequisite for understanding why the widespread use of infiltration in electrode preparation improves the electrocatalytic properties of solid electrodes. Another consequence of results reported herein is recognition that compounds such as $\mathrm{Ba}_{3} \mathrm{Mn}_{2} \mathrm{O}_{8}$ that include a highly oxidized transition metal can serve as a "storage" compound for the transition metal until polarization is applied and the transition metal having high electrocatalytic activity is "released" or redistributed onto the electrode surface. Further research is however needed in order to explorer this intriguing concept in more detail.

\section{Experimental Section}

\subsection{Sample architecture and materials selection}

In commercial applications of infiltrated LSM electrodes, the electrode is typically a porous composite electrode with the primarily electron-conducting LSM perovskite entangled with an oxygen-ion conducting electrolyte. ${ }^{[54,55]}$ Common electrolyte materials are YSZ for operating temperatures $>600{ }^{\circ} \mathrm{C}$ and CGO for operating temperatures $<600{ }^{\circ} \mathrm{C} .{ }^{[56]}$ However, in this work the majority of the in operando experiments were performed using a thin film model electrode in order to ensure uniform polarization of the electrode. To assure consistency between thin film model electrodes and conventional porous composite electrodes, 


\section{WILEY-VCH}

both electrode types were fabricated and Raman spectra were recorded from each electrode type. Sketches of the electrochemical cells with thin film and porous electrodes respectively are shown in Figure 7.

a)

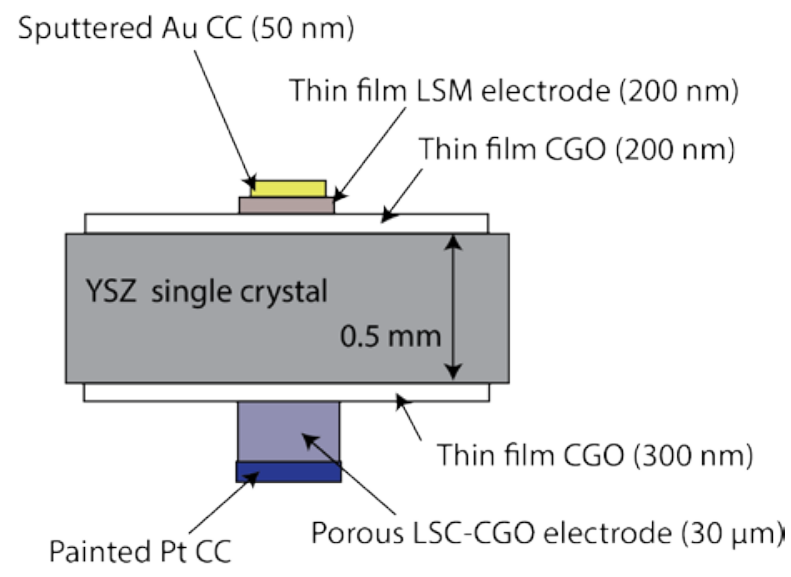

b)

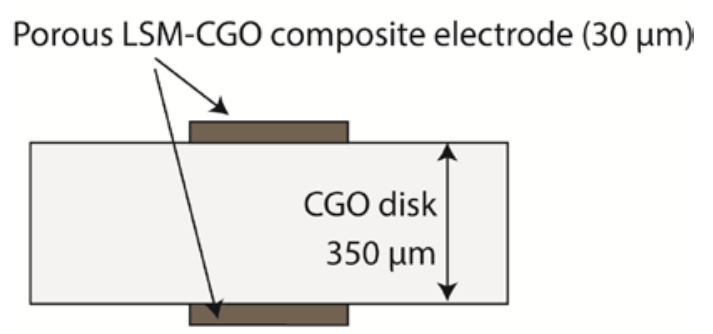

Figure 7. Sketch of the electrochemical cells applied in this work a) the thin film model cell and b) the "conventional cell” with porous LSM-CGO electrode. CC denotes the current collector.

Experiments described below used LSM as the electron conducting phase due to this material's structural stability and its widespread usage in solid oxide electrolysis/fuel cells ${ }^{[54,}$ ${ }^{57,58]}$ and electrochemical cells intended to remediate $\mathrm{NO}_{\mathrm{x}}$ pollutants from diesel exhaust 


\section{WILEY-VCH}

streams. ${ }^{[20]}$ Gadolinium-doped ceria (CGO) served as the electrolyte phase in the conventional cells with porous electrodes due to CGO's high oxygen ion conductivity at comparatively low temperatures $\left(<600{ }^{\circ} \mathrm{C}\right) \cdot{ }^{[56]}$ Furthermore, a CGO thin film layer was applied adjacent to the LSM thin film electrode in the thin film model cell to mimic the materials composition of the conventional cells. For the thin film model cell, a YSZ single crystal served as both the electrolyte and substrate for the CGO and LSM thin films due to the lack of commercially available CGO single crystals. In accordance with these considerations, LSM15 ( $\left.\left(\mathrm{La}_{0.85} \mathrm{Sr}_{0.15}\right)_{0.9} \mathrm{MnO}_{3 \pm \delta}\right), \mathrm{CGO} 10\left(\mathrm{Ce}_{0.90} \mathrm{Gd}_{0.10} \mathrm{O}_{1.95}\right)$ and for the thin film samples additionally YSZ $\left(\left(\mathrm{Y}_{2} \mathrm{O}_{3}\right)_{9.5}\left(\mathrm{ZrO}_{2}\right)_{90.5}\right)$, were used in the experiments described below.

\subsection{Fabrication of electrochemical thin film model cell}

The thin film model cell was designed to mimic conventional cells with a composite electrode consisting of an oxygen conducting CGO phase and an electronic conducting LSM phase. A previous study on this type of model cell has been reported elsewhere with further details on the cell preparation ${ }^{[48]}$. The YSZ single crystals (CrysTeC GmbH, Germany) that served as electrolyte and substrate for the thin films had a (100) exposed face, were single side polished and measured $2.54 \mathrm{~cm}$ in diameter. The LSM thin film electrode and thin films of CGO were deposited on the YSZ using pulsed laser deposition (PLD) with a KrF excimer laser. During the depositions, the fluence was $2 \mathrm{Jcm}^{-2}$ with a laser frequency of $10 \mathrm{~Hz}$ and the distance between the substrate and target was $7.5 \mathrm{~cm}$. The CGO thin films (200-300 nm) were deposited at a substrate temperature of $700^{\circ} \mathrm{C}$ and oxygen partial pressure of $5 \times 10^{-4} \mathrm{mbar}$ on both the polished and the rough side of the YSZ single crystal. The LSM thin film electrode ( $\approx 200 \mathrm{~nm}$ ) was deposited on top of the CGO layer on the polished side of the YSZ single crystal and a shadow mask maintained LSM thin film electrode dimensions of $0.5 \mathrm{~cm} \times 1 \mathrm{~cm}$. The LSM deposition was conducted with a substrate temperature of $600^{\circ} \mathrm{C}$ and with oxygen 


\section{WILEY-VCH}

partial pressure at $7 \times 10^{-4} \mathrm{mbar}$. The oxygen partial pressure was increased to $0.02 \mathrm{mbar}$ immediately after the deposition and during cool-down to avoid oxygen deficiencies from developing in the LSM electrode. An LSC-CGO (50 wt $\%\left(\mathrm{La}_{0.6} \mathrm{Sr}_{0.4}\right)_{0.99} \mathrm{CoO}_{3}-50 \mathrm{wt} \%$ $\left.\mathrm{Ce}_{0.9} \mathrm{Gd}_{0.1} \mathrm{O}_{1.95}\right)$ porous electrode $(30 \mu \mathrm{m})$ was screen-printed as a "counter-electrode" to the thin film LSM electrode and was deposited on top of the CGO thin film on the rough side of the YSZ single crystal. Following the application of the LSC-CGO electrode, the entire electrochemical cell was heated to $930^{\circ} \mathrm{C}$ for $24 \mathrm{~h}$. A Pt current collector was painted on the LSC-CGO electrode and sintered at $900{ }^{\circ} \mathrm{C}$ for $2 \mathrm{~h}$. Finally, Au was sputtered onto the thin film electrode and the cell was heat-treated at $700{ }^{\circ} \mathrm{C}$ for $120 \mathrm{~h}$ allowing the Au to sinter, with the intention of forming a continuous Au network for current collection. As subsequent imaging revealed the formation of separate $\mu \mathrm{m}$-sized Au particles rather than an Au network, adequate current collection was obtained by applying an Au mesh in the final test-set-up. The complete architecture of the thin film model cell is shown in Figure 7 a) and a SEM image of the LSM thin film electrode and the adjacent layers is found in SI-7.

\subsection{Preparation of “conventional” electrochemical cell with porous LSM-CGO}

\section{electrodes}

Electrochemical cells with porous LSM-CGO composite electrodes were prepared as follows: a CGO10 (Rhodia) electrolyte with 1\% Fe added as a sintering aid was tape-casted, stamped out in disks and sintered at a maximum temperature of $1250^{\circ} \mathrm{C}$ for $4 \mathrm{~h}$. After sintering, the electrolyte disks were dense, $350 \mu \mathrm{m}$ thick and had a diameter of $23 \mathrm{~mm}$. A circular $10 \mathrm{~mm}$ diameter 50 wt\% LSM15 - 50 wt\% CGO10 composite electrode was screen-printed onto each side of the CGO electrolyte disks and sintered with the maximum temperature of $1050{ }^{\circ} \mathrm{C}$ for $2 \mathrm{~h}$, resulting in $\approx 30 \mu \mathrm{m}$ thick porous electrodes. A sketch of the cell with porous LSM-CGO electrodes is shown in Figure $7 \mathrm{~b}$ ) 


\subsection{Addition of $\mathrm{BaO}$}

$\mathrm{BaO}$ was added to both a dense, thin film LSM electrode and a porous LSM-CGO electrode. Due to reaction with $\mathrm{CO}_{2}$ in the atmosphere and reaction with the electrode components, the majority of the $\mathrm{Ba}$ added was present as $\mathrm{BaCO}_{3}$ or as $\mathrm{Ba}-\mathrm{Mn}-\mathrm{O}$ compounds (vide supra) throughout the in operando experiments; however for brevity, these samples are referred to as BaO-infiltrated samples. Due to differences in sample architecture between the thin film LSM electrode and a porous LSM-CGO electrode, slightly different procedures were used for the $\mathrm{BaO}$ addition. The porous LSM-CGO electrodes were infiltrated by adding a droplet of 0.32 $\mathrm{M} \mathrm{Ba}\left(\mathrm{NO}_{3}\right)_{2}$ (aq) onto the electrode surface and the solution was allowed to soak into the porous structure. Excess solution was removed from the surface and the infiltrated cells were heat-treated at $700{ }^{\circ} \mathrm{C}$ for $1 \mathrm{~h}$ to decompose the $\mathrm{Ba}\left(\mathrm{NO}_{3}\right)_{2}$ into $\mathrm{BaO}$. This procedure was repeated 7 times to obtain a uniform coverage of $\approx 50 \mathrm{~nm} \mathrm{BaO}$ particles throughout the electrodes. A similar procedure was employed for deposition of $\mathrm{Ba}\left(\mathrm{NO}_{3}\right)_{2}$ onto the LSM thin film electrodes, where an aqueous $0.032 \mathrm{M} \mathrm{Ba}\left(\mathrm{NO}_{3}\right)_{2}$ solution containing $10 \mathrm{wt} \% \mathrm{P} 123$ dispersant (BASF) was used. Excess solution on the thin film electrodes was not wiped off of the surface prior to the heat-treatment at $700{ }^{\circ} \mathrm{C}$ and the $\mathrm{Ba}\left(\mathrm{NO}_{3}\right)_{2}$ deposition step was only performed once. This procedure resulted in large agglomerations of $\mathrm{BaO}$ on some areas of the electrode (Figure 8a), while in other areas nanosized $\mathrm{BaO}$ particles were well dispersed on the electrode surface as intended. It is emphasized that the in operando Raman spectroscopy reported in this paper was conducted on the electrode area with well-dispersed BaO. Topview SEM images of an electrode area with $\mathrm{BaO}$ present as nanoparticles is shown in Figure 8b and a bare LSM thin film electrode for comparison is shown in Figure 8c. The BaO particles on the surface caused the $\mathrm{BaO}$ treated electrode to appear more "roughened” (Figure 8b) compared to the non-infiltrated surface (Figure 8c). 


\section{WILEY-VCH}
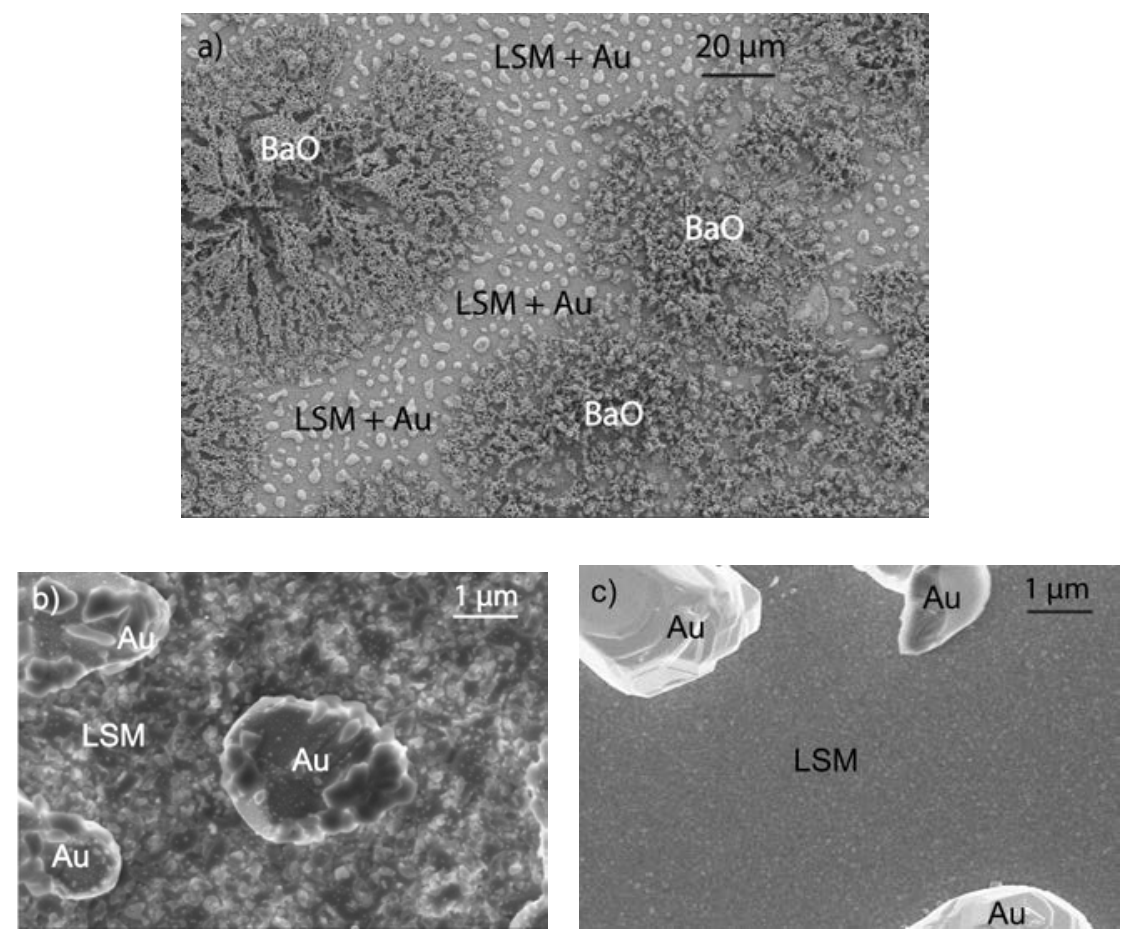

Figure 8. Top-view SEM images of the LSM thin film electrodes a, b) with $\mathrm{BaO}$ deposition and c) without $\mathrm{BaO}$ deposition.

\subsection{SEM}

Electrode surfaces and cross-sections of broken cells were investigated with scanning electron microscopy (SEM) on a Zeiss Supra 35 microscope. The microstructure of the electrode surfaces was investigated using the InLens detector with a $5 \mathrm{kV}$ acceleration voltage and without any pre-treatment of the electrode. The thickness of the thin film layers of broken cross-sections was determined using the backscattered electron detector with a $10 \mathrm{kV}$ acceleration voltage and the cross sections were carbon coated to avoid charging of the sample.

\subsection{TOF-SIMS}

Analysis of the elemental distribution through LSM thin film electrodes without and with $\mathrm{BaO}$ deposition was performed with Time-of-Flight Secondary Ion Mass Spectrometry (TOFSIMS) using a TOF-SIMS IV (ION-TOF GmbH, Münster, Germany). The 25 ns pulses of 25 


\section{WILEY-VCH}

$\mathrm{keV} \mathrm{Bi}^{+}$(primary ions) were used at a repetition rate of $10 \mathrm{kHz}$, yielding a target current of $0.7 \mathrm{pA}$. Depth profiling was performed with approximately $2 \mathrm{~nm}$ depth resolution on a $200 \times 200 \mu \mathrm{m}^{2}$ surface analysis area centered in a $300 \times 300 \mu \mathrm{m}^{2}$ sputter area. The $30 \mathrm{nA}$ of 3 $\mathrm{keV} \mathrm{Xe}^{+}$was used as sputter ions (10 s sputtering, $1 \mathrm{~s}$ pause and then analysis using one scan and $256 \times 256$ pixels). For all analyses electron bombardment $(20 \mathrm{eV})$ was used to minimize charge built-up at the surface. Desorbed secondary ions were accelerated to $2 \mathrm{keV}$, mass analyzed in the flight tube, and post-accelerated to $10 \mathrm{keV}$ before detection.

\subsection{XPS}

The surface stoichiometry of four LSM thin film electrodes without BaO deposition were analysed with X-ray photoelectron spectroscopy (XPS) performed on a K-alpha (Thermo Electron Limited, Winsford, UK) using a monochromated Al-K- $\alpha$ X-ray source and a take-off angle of $90^{\circ}$ from the surface plane. Atomic concentrations were determined from surface spectra (0-1350 eV, $100 \mathrm{eV}$ detector pass energy) and were calculated by determining the relevant integral peak intensities using a Shirley type background. Each sample surface was analyzed at three different surface locations and the average value for all four samples is reported in the results section.

\subsection{Raman Spectroscopy}

In operando Raman spectra were acquired using a Renishaw InVia spectrometer with a 488 nm Ar-ion laser and Pelletier cooled charge-coupled device (CCD) detector. The cells were mounted in an assembly developed originally to perform in operando studies of solid oxide cells and has been described in more detail elsewhere. ${ }^{[59,60]}$ Cells were fixed on the end of an YSZ tube with YS2B glass paste (IRD Fuel Cell AS) and gold wires were attached to the current collectors for electrochemical measurements. This assembly was then enclosed with a quartz tube (Quark Glass) and placed inside a tube furnace. Optical access to the thin film 


\section{WILEY-VCH}

electrode was maintained for Raman spectroscopic measurements and visual inspection. In this system, the cell was tested in a two-atmosphere environment at elevated temperatures. The laser power out of the spectrometer was $18 \mathrm{~mW}$ and this laser power was selected to give the best possible signal-to-noise ratio without causing damage to the samples. It is noted that due to scattering losses from the optics the power was slightly lower at the electrode surface.During the in operando experiments, Raman spectra with 20 s exposure times were continuously collected to record changes in the surface species under applied potential.

\subsection{Electrochemical characterization}

A potential was applied on the electrochemical cell using a Gamry Reference 600 potentiostat to record chronoamperometry curves. The applied potential difference was either $-1 \mathrm{~V}$ or $+1 \mathrm{~V}$ and the potential difference was predominantly across the thin film electrode, as the resistance of the porous LSC-CGO electrode was $<1 \%$ of the resistance of the LSM thin film electrode. This was experimentally confirmed by using electrochemical impedance spectroscopy to determine the polarization resistance on symmetric cells with two LSC-CGO electrodes and on cells with one LSC-CGO electrode and one LSM thins film electrode, respectively.

\subsection{Overall experimental sequence}

In operando Raman spectra were acquired from a BaO-modified LSM thin film cell during 15 individual polarization experiments that comprised a single overall experimental sequence. At the beginning of the sequence the cell was exposed to a constant gas flow of $10 \% \mathrm{O}_{2}$ in $\mathrm{Ar}$ and heated to $500{ }^{\circ} \mathrm{C}$. When at $500{ }^{\circ} \mathrm{C}$, the individual experiments were conducted at $-1 \mathrm{~V}$ or $+1 \mathrm{~V}$. The temperature was then reduced to $300{ }^{\circ} \mathrm{C}$ and experiments were repeated. During the experimental sequence, the cell was constantly subjected to a gas flow containing $10 \% \mathrm{O}_{2}$. 


\section{WILEY-VCH}

\subsection{XRD}

For phase-determination on the screen-printed electrodes and synthesized $\mathrm{Ba}_{3} \mathrm{Mn}_{2} \mathrm{O}_{8}$ (see next section), XRD measurements were performed at room temperature with a Bruker D8 XRay Diffractometer (Bruker-Siemens, Germany) using $\mathrm{Cu}$ Ko radiation with an acceleration voltage of $40 \mathrm{kV}$ and a filament current of $40 \mathrm{~mA}$. The recorded spectra were background corrected using the EVA software (Bruker), and the crystallographic database available in the EVA software was used to identify the present phases.

\subsection{Reference materials}

During the course of the in operando Raman experiments, vibrational bands appeared that could not be assigned to the original materials. Consequently, several new 'candidate' materials were chosen for analysis and served as spectroscopic reference data. Many of these materials were available from traditional sources and/or spectra were already available from the literature. These materials included $\mathrm{SrO}^{[61]}, \mathrm{La}_{2} \mathrm{O}_{3}{ }^{[62]}, \mathrm{Mn}_{2} \mathrm{O}_{3}{ }^{[32,33,36]}, \mathrm{Mn}_{3} \mathrm{O}_{4}{ }^{[32,33,36]}$, $\mathrm{MnO}_{2}{ }^{[32,33,36]}, \mathrm{MnO}^{[32]}, \mathrm{BaO}^{[63,64]}$, and $\mathrm{BaMnO}_{3}{ }^{[65]}$. One material that was relatively poorly characterized by Raman spectroscopy was $\mathrm{Ba}_{3} \mathrm{Mn}_{2} \mathrm{O}_{8}$, which was synthesized in our own laboratory and characterized by XRD and Raman spectroscopy; see SI-2 for further information about synthesis and characterization of this material.

\section{Supporting Information}

Supporting Information is available from the Wiley Online Library or from the author.

\section{Acknowledgements}

M. L Traulsen gratefully acknowledges support from the Danish Independent Research Council - Technology and Production (12-131965). R. A. Walker gratefully acknowledges 


\section{WILEY-VCH}

support from the U.S. Office of Naval Research (N000141410326). M.D. McIntyre gratefully acknowledges support from the U.S. National Science Foundation Division of Material Research (1411210).

Received: ((will be filled in by the editorial staff))

Revised: ((will be filled in by the editorial staff))

Published online: ((will be filled in by the editorial staff)) 


\section{WILEY-VCH}

\section{References}

[1] J. Larminie, A. Dicks, Fuel Cell Systems Explained, 2nd edition, John Wiley \& Sons Ltd, England 2003.

[2] M. A. Laguna-Bercero, J. Power Sources. 2012, 203, 4.

[3] K. K. Hansen, Appl. Catal. , B. 2010, 100, 427.

[4] S. P. Jiang, Mater. Sci. Eng. A. 2006, 418, 199.

[5] D. Ding, X. Li, S. Y. Lai, K. Gerdes, M. Liu, Energy Environ. Sci. 2014, 7, 552.

[6] A. J. Samson, M. Sogaard, P. Hjalmarsson, J. Hjelm, N. Bonanos, S. P. V. Foghmoes, T. Ramos, Fuel Cells. 2013, 13, 511.

[7] N. Ai, S. P. Jiang, Z. Lue, K. Chen, W. Su, J. Electrochem. Soc. 2010, 157, B1033.

[8] M. Sase, K. Yashiro, K. Sato, J. Mizusaki, T. Kawada, N. Sakai, K. Yamaji, T. Horita, H. Yokokawa, Solid State Ionics. 2008, 178, 1843.

[9] J. Hayd, H. Yokokawa, E. Ivers-Tiffee, J. Electrochem. Soc. 2013, 160, F351.

[10] E. Mutoro, E. J. Crumlin, M. D. Biegalski, H. M. Christen, Y. Shao-Horn, Energy Environ. Sci. 2011, 4.

[11] M. Backhaus-Ricoult, K. Adib, T. St.Clair, B. Luerssen, L. Gregoratti, A. Barinov, Solid State Ionics. 2008, 179, 891.

[12] E. Siebert, A. Boréave, F. Gaillard, T. Pagnier, Solid State Ionics. 2013, 247-248, 30.

[13] C. W. Sun, R. Hui, J. Roller, J. Solid State Electrochem. 2010, 14, 1125. 


\section{WILEY-VCH}

[14] Y. Huang, J. M. Vohs, R. J. Gorte, Electrochem. Solid-State Lett. 2006, 9, A237.

[15] T. Z. Sholklapper, C. Lu, C. P. Jacobson, S. J. Visco, L. C. De Jonghe, Electrochem. Solid-State Lett. 2006, 9, A376.

[16] J. M. Vohs, R. J. Gorte, Adv Mater. 2009, 21, 943.

[17] V. A. C. Haanappel, D. Rutenbeck, A. Mai, S. Uhlenbruck, D. Sebold, H. Wesemeyer, B. Rowekamp, C. Tropartz, F. Tietz, J. Power Sources. 2004, 130, 119.

[18] C. C. Kan, E. D. Wachsman, J. Electrochem. Soc. 2009, 156, B695.

[19] F. Bidrawn, G. Kim, N. Aramrueang, J. M. Vohs, R. J. Gorte, J. Power Sources. 2010, 195, 720.

[20] R. M. L. Werchmeister, K. K. Hansen, M. Mogensen, Mater. Res. Bull. 2010, 45, 1554.

[21] M. L. Traulsen, K. B. Andersen, K. K. Hansen, J. Mater. Chem. 2012, 22, 11792.

[22] J. Shao, K. K. Hansen, J. Mater. Chem. A. 2013, 1, 7137.

[23] D. Ippolito, K. B. Andersen, K. K. Hansen, J. Electrochem. Soc. 2012, 159, P57.

[24] T. Hong, F. Chen, C. Xia, Electrochem. Commun. 2015, 51, 93.

[25] J. Shao, K. K. Hansen, J. Electrochem. Soc. 2013, 160, H494.

[26] K. Norrman, K. V. Hansen, T. Jacobsen, RSC advances. 2015, 5, 87679.

[27] W. Wang, S. P. Jiang, Solid State Ionics. 2006, 177, 1361.

[28] J. Druce, H. Tellez, J. Hyodo, MRS Bull. 2014, 39, 810. 


\section{WILEY-VCH}

[29] M. T. Weller, S. J. Skinner, Acta Crystallogr. , Sect. C: Cryst. Struct. Commun. 1999, 55, 154.

[30] A. Feinberg, C. H. Perry, J. Phys. Chem. Solids. 1981, 42, 513.

[31] E. F. Lopez, V. S. Escribano, M. Panizza, M. M. Carnasciali, G. Busca, J. Mater. Chem. 2001, 11, 1891.

[32] M. C. Bernard, A. H. Goff, B. V. Thi, S. C. Detorresi, J. Electrochem. Soc. 1993, 140, 3065.

[33] F. Buciuman, F. Patcas, R. Craciun, D. Zahn, Phys. Chem. Chem. Phys. 1999, 1, 185.

[34] E. Widjaja, J. T. Sampanthar, Anal. Chim. Acta. 2007, 585, 241.

[35] T. Gao, H. Fjellvag, P. Norby, Anal. Chim. Acta. 2009, 648, 235.

[36] W. Hong, M. Ueda, S. Iwamoto, S. Hosokawa, K. Wada, M. Inoue, Catal. Lett. 2012, 142, 32.

[37] N. Mironova-Ulmane, A. Kuzmin, M. Grube, J. Alloys Compounds. 2009, 480, 97.

[38] W. Kaabar, S. Bott, R. Devonshire, Spectrochim. Acta Mol. Biomol. Spectrosc. 2011, 78, 136.

[39] B. Banov, A. Momchilov, M. Massot, C. M. Julien, Mater. Sci. Eng. , B. 2003, 100, 87.

[40] D. Uy, K. Wiegand, A. O'Neill, M. Dearth, W. Weber, J. Phys. Chem. B. 2002, 106, 387.

[41] C. B. Azzoni, M. C. Mozzati, P. Galinetto, A. Paleari, V. Massarotti, D. Capsoni, M. Bini, Solid State Commun. 1999, 112, 375. 


\section{WILEY-VCH}

[42] J. Roos, C. Eames, S. M. Wood, A. Whiteside, M. S. Islam, Phys. Chem. Chem. Phys. 2015, 17, 22259.

[43] A. Hammouche, E. Siebert, A. Hammou, M. Kleitz, A. Caneiro, J. Electrochem. Soc. 1991, 138, 1212.

[44] J. Mizusaki, N. Mori, H. Takai, Y. Yonemura, H. Minamiue, H. Tagawa, M. Dokiya, H. Inaba, K. Naraya, T. Sasamoto, T. Hashimoto, Solid State Ionics. 2000, 129, 163.

[45] B. Zachau-Christiansen, T. Jacobsen, S. Skaarup, SOFC V. 1997, 97-40, 795.

[46] M. K. Mahapatra, S. Bhowmick, N. Li, P. Singh, J. Eur. Ceram. Soc. 2012, 32, 2341.

[47] E. C. Samulon, Dissertation thesis. 2011, Stanford University.

[48] M. D. McIntyre, M. L. Traulsen, K. Norrman, S. Sanna, R. A. Walker, ECS Trans. 2015, $66,47$.

[49] A. Chakraborty, P. Devi, H. Maiti, J. Mater. Res. 1995, 10, 918.

[50] W. Lee, J. W. Han, Y. Chen, Z. Cai, B. Yildiz, J. Am. Chem. Soc. 2013, 135, 7909.

[51] M. L. Traulsen, K. Kammer Hansen, J. Electrochem. Soc. 2011, 158.

[52] A. Babaei, L. Zhang, E. Liu, S. P. Jiang, J. Alloys Compounds. 2011, 509, 4781.

[53] A. J. McEvoy, Solid State Ionics. 2000, 135, 331.

[54] S. P. Jiang, J. Mater. Sci. 2008, 43, 6799.

[55] Y. Yoshinobu, Y. Tsuda, H. Ueda, Y. Nakanishi, J. Gong, SAE Int.J.Fuels Lubr. 2010, 3, 50. 


\section{WILEY-VCH}

[56] B. Dalslet, P. Blennow, P. V. Hendriksen, N. Bonanos, D. Lybye, M. Mogensen, J. of Solid State Electrochem. 2006, 10, 547.

[57] S. Adler, Chem. Rev. 2004, 104, 4791.

[58] A. Hauch, S. D. Ebbesen, S. H. Jensen, M. Mogensen, J. Mater. Chem. 2008, 18, 2331.

[59] M. B. Pomfret, J. C. Owrutsky, R. A. Walker, J. Phys. Chem. B. 2006, 110, 17305.

[60] M. B. Pomfret, J. C. Owrutsky, R. A. Walker, Annu. Rev. Anal. Chem. 2010, 3, 151.

[61] K. H. Rieder, B. A. Weinstein, M. Cardona, H. Bilz, Phys. Rev. B. 1973, 8, 4780.

[62] A. Orera, G. Larraz, M. L. Sanjuan, J. Eur. Ceram. Soc. 2013, 33, 2103.

[63] G. Mestl, M. P. Rosynek, J. H. Lunsford, J. Phys. Chem. B. 1998, 102, 154.

[64] D. de Waal, K. Range, M. Konigstein, W. Kiefer, J. Raman Spectrosc. 1998, 29, 109.

[65] C. Roy, R. C. Budhani, J. Appl. Phys. 1999, 85, 3124. 


\section{WILEY-VCH}

The table of contents entry:

In operando Raman spectroscopy reveals unexpected changes in the surface composition of $\mathrm{BaO}$ infiltrated LSM electrodes during operation. A secondary $\mathrm{Ba}_{3} \mathrm{Mn}_{2} \mathrm{O}_{8}$ phase forms during fabrication and reversibly decomposes during cathodic polarization leading to $\mathrm{MnO}_{\mathrm{x}}$ accumulation at the electrode surface. These changes illustrate that infiltrated electrode performance may arise from unanticipated changes in composition that can only be monitored in operando.

Keywords: fuel cells, in operando, LSM, Raman spectroscopy, infiltration

M. L. Traulsen*, M. D. McIntyre, K. Norrman, S. Sanna, M. B. Mogensen and R. A. Walker Reversible Decomposition of Secondary Phases in BaO Infiltrated LSM Electrodes Polarization Effects

ToC figure

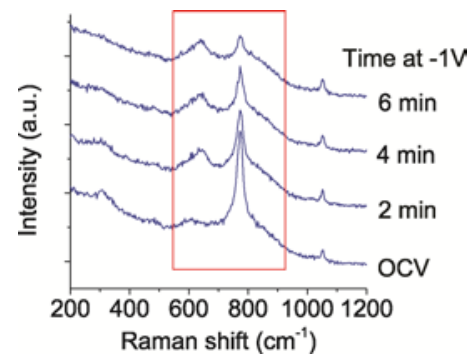


WILEY-VCH 